\title{
Meningkatkan Kemampuan Motorik Halus Dengan Menggunakan Metode Demonstrasi Pada Anak Usia 3-4 Tahun Kelompok A Di Paud Riyadlusshibyan Lendangre Tahun Ajaran 2019/2020.
}

\author{
${ }^{1}$ Lalu Marzoan, ${ }^{2}$ M.Arzani \\ ${ }^{12}$ Dosen STKIP Hamzar \\ Email: zoanzakiya12@gmail.com ${ }^{1}$, zanarzan25@gmail.com ${ }^{2}$
}

\begin{abstract}
Abstrak
Penelitian ini bertujuan untuk mengetahui peningkatan kemampuan motorik halus dengan menggunakan metode demonstrasi di PAUD Riyadlusshibyan. Metode penelitian yang digunakan dalam penelitian ini adalah metode Penelitian Timdakan Kelas (PTK) model kurt lewin dengan mengacu pada empat kegiatan pokok yang terdiri dari perencanaan (planing), pelaksanaan (acting), pengamatan (observating), dan refleksi (reflecting). Pelaksanaan ini dilaksanakan di PAUD Riyadlusshibyan, kelompok A dengan jumlah peserta didik sebanyak 21 orang. Pengumpulan data menggunakan teknik observasi, wawancara, dan dokumentasi. Hasil penelitian menunjukkan bahwa pembelajaran dengan menggunakan metode demonstrasi dapat meningkatkan motorik halus anak, perkembangan motorik halus anak yang dianalisa terdiri dari empat aspek, yaitu : ketelitian, kecepatan, kelenturan, dan kerapian. Dari analisa data menunjukkan adanya peningkatkan pada setiap siklusnya, ini dapat dilihat dari pra tindakan di peroleh nilai rata-rata motorik halus anak 49,33, pada siklus I rata-rata motorik halus anak naik menjadi 87,24, kemudian meningkat sebesar 96,10 pada siklus II.
\end{abstract}

\section{Kata kunci : Motorik Halus, Metode Demonstrasi}

\section{PENDAHULUAN}

Tujuan diselenggarakan Pendidikan Anak Usia Dini adalah untuk membentuk anak Indonesia yang berkualitas, yaitu anak yang tumbuh dan berkembang sesuai dengan tingkat perkembangannya, sehingga memiliki kesiapan yang optimal didalam memasuki pendidikan dasar serta mengarungi kehidupan dimasa dewasa dan membantu menyiapkan anak untuk mencapai kesiapan belajar (akademik) di sekolah. (Risaldy, 2014 : 17).

Untuk mencapai tujuan tersebut, yang harus dilakukan oleh guru adalah memberikan metode pembelajaran yang sesuai dengan tingkat perkembangan anak, salah satunya adalah dengan metode demonstrasi. Metode demonstrasi ini harus diberikan kepada peserta didik secara berkelanjutan dan berkala. Sedangkan yang harus dilakukan oleh peserta didik adalah mematuhi apa yang diperintahkan guru dan memperhatikan yang dicontohkan.

Perkembangan motorik halus anak tidak hanya ditentukan oleh pembawaan dalam diri

setiap peserta didik, namun juga ditentukan oleh peran pendidik (guru) dan juga sarana prasana yang mendukung. Guru dan sekolah adalah dua hal yang tidak dapat dipisahkan. Guru mempunyai peran sebagai translator ilmu, sedangkan sekolah adalah sebagai wadah setiap peserta didik untuk menuntut ilmu dan mengembangkan bakat bawaan Metode demonstrasi ini sesuai untuk mengajarkan bahan-bahan pelajaran yang merupakan suatu gerakan-gerakan, suatu proses maupun hal-hal yang bersifat rutin. Dengan metode demonstrasi peserta didik berkesempatan mengembangkan kemampuan mengamati segala benda yang sedang terlibat dalam proses serta dapat mengambil kesimpulan-kesimpulan yang diharapkan (Syaiful, 2006:210).

Suyadi (1982) menerangkan bahwa Pendidikan PAUD dilaksanakan dengan prinsip "bermain sambil belajar atau belajar seraya bermain". Sesuai dengan perkembangan, oleh sebab itu diharapkan seorang pendidik yang kreatif, inovatif agar anak bisa merasa senang, tenang dan nyaman dalam proses belajar mengajar. Dalam 
standar kompetensi kurikulum PAUD tercantum bahwa tujuan pendiikan di PAUD adalah membantu mengembangkan berbagai potensi anak baik psikis dan fisik yang meliputi moral dan nilai-nilai agama, sosial emosional, kognitif, bahasa, fisik (motorik), kemandirian dan seni, untuk memasuki pendidikan dasar.

tujuan dari penelitian ini adalah Untuk meningkatkan kemampuan motorik halus dengan menggunakan metode demonstrasi pada anak usia 3-4 tahun di PAUD Riyadlusshibyan, desa lembah Sari Batu Layar

\section{KAJIAN TEORI}

\section{a. Kemampuan Motorik Halus Anak}

Kemampuan atau skill adalah berasal dari kata dasar mampu yang dalam hubungannya dengan tugas atau pekerjaan berarti dapat (kata sifat/keadaan) melakukan tugas atau pekerjaan sehingga menghasilkan barang atau jasa sesuai dengan yang diharapkan. Kemampuan dengan sendirinya juga kata sifat/keadaan ditujukan kepada sifat atau keadaan seseorang yang dapat melakukan tugas atau pekerjaan atas dasar ketentuan yang ada. (Iskandar, 2011).

Kemampuan adalah sifat lahir dan dipelajari yang memungkinkan seseorang dapat menyelesaikan pekerjaan. Adapun apa yang harus dimiliki oleh seseorang dalam menghadapi pekerjaannya menurut Mitzberg seperti yang dikutip Gibson, ada empat kemampuan (kualitas atau skill) yang harus dimiliki oleh seseorang dalam menjalankan tugas-tugasnya sebagai berikut :

1. Kemampuan teknis, adalah kemampuan untuk menggunakan alat-alat prosedur dan teknik suatu bidang khusus.

2. Keterampilan manusia, adalah kemampuan untuk bekerja dengan orang lain, baik sebagai perorangan maupun sebagai kelompok.

3. Keterampilan konseptual, adalah kemampuan mental untuk mengkoordinasikan dan memadukan semua kepentingan serta kegiatan organisasi.

Motorik merupakan terjemahan dari kata "motor" yang artinya dasar mekanika yang menyebabkan terjadinya suatu gerak. Gerak (movement) adalah suatu aktivitas yang didasari oleh proses motorik. Movement adalah gerak yang bersifat eksternal atau dari luar yang mudah diamati, sedangkan motor adalah gerak yang bersifat internal atau dari dalam, konstan, dan sukar diamati.

Prinsip utama perkembangan motorik yaitu :

1. Kematangan

2. Motivasi

3. Pengalaman

4. Praktik

(Kadri, 2014).

\section{Motorik Halus}

Motorik halus adalah pengorganisasian penggunaan sekelompok otot-otot kecil seperti jari-jemari dan tangan yang sering membutuhkan kecermatan dan koordinasi dengan tangan, ketrampilan yang mencakup pemanfaatan menggunakan alat-alat untuk mengerjakan suatu objek (Sumantri, 2005 : 143)

Motorik halus anak adalah gerakan yang hanya melibatkan bagian-bagian tubuh tertentu saja dan dilakukan oleh otot-otot kecil (halus), seperti keterampilan menggunakan jari-jari tangan dan gerakan pergelangan yang tepat. Oleh karena itu, gerakan ini tidak terlalu menggunakan tenaga, namun gerakan ini membutuhkan koordinasi mata dan tangan yang cermat. Dalam melakukan gerakan motorik halus anak juga memerlukan dukungan keterampilan fisik serta kematangan mental (Semiawan, 2003).

Indikator Motorik Halus yaitu 1. Ketelitian, 2. Kecepatan, 3. Kelenturan, 4. Kerapian Macam-macam Motorik Halus :

\section{$>$ Untuk anak usia 3 tahun:}

1. Menggambar mengikuti bentuk

2. Menarik garis vertikal, menjiplak bentuk

3. Membuka menutup kotak

4. Menggunting kertas mengikuti pola garis lurus.

Untuk anak usia 4 tahun :

1. Menggambar sesuatu yang diketahui, bukan yang dilihat.

2. Mulai menulis sesuatu dan mampu mengontrol gerakan tangannya. 
3. Menggunting zig zag, melengkung, membentuk dengan lilin.

4. Menyelesaikan puzzle 4 keping (Semiawan, 2003).

\section{b. Metode Demonstrasi Untuk Anak Usia 3-4 Tahun}

Metode adalah cara yang digunakan untuk mengimplementasikan rencana yang sudah disusun dalam kegiatan nyata agar tujuan yang telah disusun tercapai secara optimal. Metode digunakan untuk merealisasikan strategi yang telah ditetapkan. Metode dalam sistem pembelajaran memegang peranan yang sangat penting. Keberhasilan implementasi pembelajaran sangat tergantung pada cara guru menggunakan metode pembelajaran. Suatu strategi pembelajaran dapat diimplementasikan melalui penggunan metode pembelajaran.

\section{a) Demonstrasi}

Demonstrasi adalah metode mengajar dengan cara memperagakan barang, kejadian, aturan, dan urutan melakukan suatu kegiatan, baik secara langsung maupun melalui penggunaan media pembelajaran yang relevan dengan pokok bahasan atau materi yang sedang disajikan (Syah, 2003:22).

Metode demonstasi ini sesuai untuk mengajarkan bahan-bahan pelajaran yang merupakan suatu gerakangerakan, suatu proses maupun hal-hal yang bersifat rutin. Dengan metode demonstrasi peserta didik berkesempatan mengembangkan kemampuan mengamati segala benda yang sedang terlibat dalam proses serta dapat mengambil kesimpulankesimpulan yang diharapkan (Syaiful, 2006:210).

Langkah-langkah melakukan metode demonstrasi :

1. Mempersiapkan alat dan bahan yang diperlukan.

2. Guru menjelaskan kepada anak-anak secara perlahan-lahan, serta memberikan penjelasan yang cukup singkat.

3. Guru mendemonstrasikan kepada anak-anak secara perlahan-lahan, serta memberikan penjelasan yang cukup singkat.

4. Guru mengulang kembali selangkah demi selangkah dan menjelaskan alasan-alasan setiap langkah.

5. Guru menugaskan kepada siswa agar melakukan demonstrasi sendiri langkah demi langkah dan disertai penjelasan. (Anisatul, 2009 : 87).

Kelebihan metode demonstrasi adalah terjadinya verbalisme akan dapat dihindari, siswa disuruh langsung memperhatikan bahan pelajaran yang dijelaskan, Proses pembelajaran akan lebih menarik, dengan cara mengamati secara langsung siswa akan memiliki kesempatan untuk membandingkan antara teori dan kenyataan.

$\begin{array}{llrr} & \text { Kekurangan } & \text { metode } \\ \text { demonstrasi } & \text { adalah } & \text { memerlukan } \\ \text { ketrampilan } & \text { guru secara } & \text { khusus, } \\ \text { memerlukan } & \text { waktu yang } & \text { banyak, } \\ \text { memerlukan } & \text { kematangan } & \text { dalam }\end{array}$
perancangan atau persiapan, keterbatasan dalam sumber belajar, alat pelajaran, situasi yang dikondisikan dan waktu untuk mendemonstrasikan (Anisatul, 2009 : 87).

\section{c. Hipotesis Tindakan}

Hipotesis dalam penelitian ini adalah penerapan metode demonstrasi dapat meningkatkan kemampuan motorik halus anak Usia 3-4 tahun di PAUD Riyadlusshibyan.

\section{METODE PENELITIAN}

Jenis penelitian ini adalah penelitin tindakan kelas (classroom action research). Penelitian tindakan kelas adalah penelitian yang dilakukan oleh guru di kelas atau disekolah tempat dia mengajar dengan penekanan pada penyempurnaan atau peningkatan proses dan praktek pembelajaran (Aqib, 2006:19). Penelitian ini merupakan salah satu upaya guru atau praktisi dalam bentuk berbagai kegiatan yang di lakukan untuk memperbaiki atau meningkatkan mutu pembelajaran di kelas. 
Penelitian tindakan kelas ini dilakukan di PAUD Riyadlusshibyan, Dusun Lendangre, Desa Lembah Sari, Kecamatan Batu Layar, Kabupaten Lombok Barat Tahun Pelajaran 2019/2020

Peneliti merasa tertarik melakukan penelitian di PAUD Riyadlusshibyan, karena peneliti melihat perkembangan motorik halus anak di lembaga ini belum berkembang secara maksimal sehingga peneliti merasa cocok melakukan penelitian dengan teknik yang mendukung dalam mengembangkan motorik halus anak.

Penelitian ini dilaksanakan pada Bulan September sampai dengan Bulan November 2019.

\section{Subyek Penelitian}

Subyek dalam penelitian ini adalah peserta didik kelompok A PAUD Riyadlusshibyan Kabupaten Lombok Barat Tahun Ajaran 2019/2020 dengan jumlah 21 peserta didik terdiri 9 perempuan dan 12 laki-laki. Obyek penelitian adalah kemampuan motorik halus dalam membuat kolase.

\section{Sumber Data}

Sumber data dalam penelitian ini terdiri dari beberapa sumber :

a. Peserta didik

Berupa kemampuan motorik halus dalam membuat kolase untuk mendapatkan hasil belajar dan aktifitas yang dilakukan oleh peserta didik/siswa dalam proses pembelajaran.

b. Guru

Kemampuan guru dalam mengelola pembelajaran untuk melihat tingkat keberhasilan implementasi pembelajaran dalam meningkatkan kemampuan motorik halus anak dengan cara bermain pasir.

c. Pengelola PAUD

Mengelola PAUD dimaksud sebagai sumber data untuk melihat implementasi PTK secara komprehensif baik dari sisi peserta didik maupun guru.

\section{Teknik dan Alat Pengumpulan Data}

Teknik pengumpulan data yaitu cara yang digunakan untuk mengumpulkan data dalam suatu penelitian. Dalam melaksanakan penelitian ada beberapa teknik yang penulis gunakan antara lain Observasi, Wawancara, Dokumentasi

\section{Validasi Data}

Data kemampuan motorik halus siswa dalam membuat kolase adalah :

\begin{tabular}{|c|c|l|}
\hline No & Indikator & \multicolumn{1}{|c|}{ Kegiatan } \\
\hline 1 & Ketelitian & $\begin{array}{l}\text { Menyiapkan Kertas } \\
\text { pola bunga }\end{array}$ \\
\hline 2 & Kecepatan & Selesai tepat waktu \\
\hline 3 & Kelenturan & $\begin{array}{l}\text { Menempel pasir pada } \\
\text { kertas pola bunga }\end{array}$ \\
\hline 4 & Kerapian & $\begin{array}{l}\text { Menyesuaikan warna } \\
\text { sesuai contoh }\end{array}$ \\
\hline
\end{tabular}

Kemudian data diatas divalidasi dengan rumus ketuntasan invividu. Adapun rumus ketuntasan individu adalah :

$$
K B=\frac{T}{T_{1}} \quad x 100 \%
$$

$$
\begin{aligned}
& \text { Keterangan : } \\
& \mathrm{KB}=\text { Ketuntasan belajar } \\
& \mathrm{T}=\text { Jumlah skor yang } \\
& \text { diperoleh } \\
& \mathrm{T}_{1} \quad=\text { Jumlah skor total } \\
& \text { (Trianto, 2010: } 214 \text { ). }
\end{aligned}
$$

\section{Analisis Data}

Analisis data dalam penelitian tindakan kelas (PTK) ini menggunakan instrumen penelitian seperti lembar observasi, pedoman wawancara, dokumentasi, foto.

Analisis data dalam PTK ini dilakukan dengan tahap: menyeleksi, menyederhanakan, mengklarifikasi, memfokuskan, membuat kesimpulan makna hasil analisis (Miles dan Hubberman diterjemahkan oleh Tjetjep, 1992:20).

Data kegiatan yang diambil setelah selesai siklus selanjutnya dihitung skor totalnya untuk setiap peserta didik sesuai dengan data yang digunakan, misal teliti atau tidak teliti, cepat atau tidak cepat, lentur atau tidak lentur, rapi atau tidak rapi. Selanjutnya skor diubah menjadi presentase $(\%)$.

Untuk mengetahui mampu atau tidaknya anak terhadap metode demonstrasi yang diterapkan 
dalam pembelajaran, maka prosent penelitian dibandingan dengan siklus ya atau tidak.

Sedangkan untuk mengetahui kemampuan siswa secara keseluruhan, maka dihitung rerata prosent dalam setiap siklus.

\section{Kerangka Berpikir}

Kondisi awal peserta didik usia 3-4 tahun kelompok belajar A di PAUD Riyadlusshibyan untuk kemampuan motorik halus masih rendah, meskipun rata-rata seluruh anak mempunyai ketelitian, namun untuk kerapian siswa masih rendah.

Ini semua dikarenakan belum pernah ada guru yang menerapkan metode demonstrasi dalam proses belajar mengajar sebelumnya. Oleh karena itu, banyak sekali siswa yang belum bisa menggunakan lem, cara untuk menempelkan pasir sesuai dengan pola dan tidak mampu menyesuaikan warna sesuai dengan contoh.

Untuk menyelesaikan masalah tersebut, sangat perlu diterapkan metode demonstrasi dalam proses belajar mengajar secara berkala. Dengan media gambar/kertas berpola, pasir, siswa akan menjadi terangsang untuk menempelkan pasir di pola dengan rapi dan termotivasi untuk membuat tugas sesuai dengan yang dicontohkan guru.

\section{Prosedur Penelitian}

Penelitian tindakan kelas yang digunakan dalam penelitian ini menggunakan model Menurut Kemmis dan MC Tanggart (2016:40) penelitian tindakan kelas dapat dipandang sebagai suatu siklus spiral dari penyusunan perancanaan, pelaksanaan tindakan, pengamatan (observasi) dan refleksi yang selanjutnya mungkin diikuti dengan siklus spiral berikutnya.

Secara umum, pada siklus PTK setiap kali putaran (siklus) terdiri atas :

\section{Planning (Perencanaan)}

Pada tahap ini peneliti membuat skenario yang dapat memudahkan peneliti melaksanakan tindakan atau pembelajaran secara efektif dan efisien dengan harapan penerapan teknik kolase dapat meningkatkan kemampuan motorik halus anak, berdasarkan pengamatan kenyataan dikelas, maka peneliti melakukan tahap perencanaan sebagai berikut :

Peneliti melakukan analisis kurikulum untuk mengetahui kompetensi dasar yang akan disampaikan kepada anak dalam kegiatan pembelajaran, membuat skenario kegiatan belajar sambil bermain (RKH), membuat lembar daftar pengamatan atau pedoman observasi untuk dijadikan acuan pengamatan dalam mengetahui perkembangan motorik halus anak yang diamati, serta bagaimana situasi dan keadaan dalam proses kegiatan pembelajaran anak, mempersiapkan berbagai media atau bahan ajar yang digunakan dalam penerapan teknik kolase, mendesain alat evaluasi atau penilaian yang digunakan untuk melihat dan mengetahui hasil pelaksanaan tindakan dan perkembangan motorik halus anak dalam kegiatan belajar sambil bermain.

\section{Acting (Tindakan)}

Pada tahap ini peneliti melaksanakan kegiatan prosrs belajar mengajar sambil bermain bersama anak dalam rangka mengembangkan motorik halus anak sesuai dengan rencana yang telah dituangkan dalam skenario pembelajaran dan tentunya dengan memilih tema sesuai dengan kurikulum PAUD. Peneliti menyediakan alat/media yang akan digunakan untuk melaksanakan kegiatan teknik kolase seperti media gambar, kertas crap dan lem, sebelum pembelajaran dimulai anak-anak terlebih dahulu berdo'a dan bernyanyi guna untuk pembugaran agar anak-anakmerasa semangat dan senang dalam mengikuti pembelajaran, sebelum alat/media teknik kolase dibagikan kepada masing-masing anak, peneliti menjelaskan langkah-langkah dalam melakukan teknik kolase, setelah itu media gambar, kertas crap dan lem dapat dibagikan kepada masing-masing anak dan kegiatanpun dapat dimulai sampai selesai.

\section{Pengamatan (Observasi)}

Pengamatan ini dilakukan terhadap proses dan hasil kegiatan pembelajaran, faktor-faktor yang diamati adalah aktivitas-aktivitas yang tampak dalam proses belajar mengajar dan semua aktivitas tersebut dicatat dalam lembar observasi yang telah disiapkan. Kegiatan ini dilakukan bersama salah satu guru PAUD Riyadlusshibyan, dan semua kejadiankejadian penting baik perubahan-perubahan yang tampak pada anak selama proses belajar mengajar berlangsung. Adapun kegiatan yang dilakukan pada tahap ini adalah : melihat kekurangan dalam kegiatan mengajar serta 
aktivitas anak dalam belajar menggunakan lembar observasi, mengadakan perbaikan untuk dilaksanakan pada siklus berikutnya.

\section{Reflektif (Refleksi)}

Kegiatan pada langkah ini adalah mencermati, mengkaji, dan menganalisis secara mendalam dan menyeluruh terhadap tindakan yang telah dilaksanakan yang didasrkan pada data yang telah terkumpul pada langkah observasi. Jika terdapat kelemahan dan kekurangan yang terjadi dari tindakan yang dilakukan pada setiap kegiatan pembelajaran dalam satu siklus, maka peneliti bersama guru akan melakukan proses pengkajian ulang pada siklus berikutnya.

\section{HASIL PENELITIAN}

Penelitian ini dilakukan pada lembaga pendidikan Anak Usia Dini (PAUD) Riyadlusshibyan Lendangre Desa Lembah Sari Kec. Batu layar Lombok Barat.

\section{Kondisi Awal}

Pada Kondisi Awal Peneliti melaksanakan pada tanggal 28 September 2019. Mengenai data hasil kemampuan motorik halus anak, data dikumpulkan menggunakan lembar observasi yang diisi oleh observer yang mengamati anak dalam proses belajar mengajar. Hasil observasi kemudian dihitung skornya untuk menentukan kategori motorik halus anak.

Kemampuan awal motorik halus anak dijabarkan dengan skala 1- 4. Data hasil observasi motorik halus anak kemudian dicari rata-ratanya dengan cara jumlah skor hasil observasi motorik halus seluruh anak dibagi dengan jumlah anak yang diobservasi, dikategorikan pada lembar observasi. Jumlah anak yang tuntas 7 orang, jumlah anak yang tidak tuntas 14 orang, sehingga ketuntasan klasikal yaitu $33 \%$.

\section{Siklus I}

Dari hasil kegiatan yang diberikan, diperoleh data hasil kemampuan motorik halus anak untuk siklus I. Data hasil kemampuan motorik halus anak dicari rata-ratanya dengan cara jumlah nilai anak dibagi dengan jumlah anak maksimal. Sedangkan ketuntasan klasikal dicari dengan jumlah anak dibagi dengan jumlah seluruh anak dikali $100 \%$. Hasil yang diproleh dari metode Demonstrasi pada siklus
I yaitu ketuntasan klasikal mencapai $43 \%$ dengan ini rata-rata motorik halus anak adalah 87, 24. Jumlah Anak yang Tuntas 16 orang, sedangkan anak yang tidak tuntas 16 orang dan ketuntasan klasikalnya 76,19\%.

Berdasarkan hasil pengamatan motorik halus anak yang dilaksanakan pada hari Rabu tanggal 11 Oktober 2019 menggunakan metode Demonstrasi. menunjukkan jumlah anak yang tuntas dari dua kali pertemuan sebanyak 9 anak, dikalikan dengan jumlah anak maksimal sehingga diperoleh nilai ratarata 87,24, dari hasil motorik halus anak dikemukakan bahwa jumlah yang tidak tuntas sebanyak 12 anak dengan ketuntasan klasikal 43\%, hal ini menunjukkan kemampuan motorik halus anak masuk kedalam kategori $\mathrm{BSH}$, ini berarti anak menunjukkan perkembangan yang cukup baik.

\section{Siklus II}

Siklus II dilaksanakan dua kali pertemuan dari hari Kamis tanggal 25 Oktober - hari Jum'at tanggal 3 November 2019, dengan tahapan sebagai berikut :

Berdasarkan hasil pengamatan motorik halus anak yang dilaksanakan pada hari Rabu tanggal 11 Oktober 2019 menggunakan metode Demonstrasi. menunjukkan jumlah anak yang tuntas dari dua kali pertemuan sebanyak 18 anak, dikalikan dengan jumlah anak maksimal sehingga diperoleh nilai ratarata 96,60, dari hasil motorik halus anak dikemukakan bahwa jumlah yang tidak tuntas sebanyak 3 anak dengan ketuntasan klasikal $86 \%$ dengan kriteria baik, dibandingankan dengan Siklus I kemampuan motorik halus anak berada masuk kategori cukup baik atau $\mathrm{BSH}$, hal ini menunjukkan kemampuan motorik halus anak pada Siklus II rata-rata berada pada kategori baik atau BSB, dimana anak mengalami kesulitan dalam menyelesaikan kegiatan yang diberikan guru dapat diminimalisir dan anak lebih termotivasi dilihat dari wajah anak yang merasa senang mendapatkan stempel bintang dari guru, ini berarti peningkatan motorik halus anak dengan metode demonstrasi menggunakan bahan pasir dengan tehnik kolase dapat dikatakan berhasil..

Nilai rata-rata motorik halus anak selama pembelajaran dengan menggunakan metode 
demonstrasi menunjukkan peningkatan pada setiap siklusnya. Pada pra tindakan diperoleh nilai rata-rata motorik halus anak adalah 49,33, pada siklus I rata-rata motorik halus anak naik menjadi 87,24, kemudian meningkat sebesar 96,10 pada siklus II.

\section{PEMBAHASAN}

Penelitian Tindakan Kelas (PTK) ini bertujuan untuk menerapkan metode demonstrasi untuk meningkatkan motorik halus anak kelompok A PAUD Riyadlusshibyan tahun pelajaran 2019. Penelitian ini dilaksanakan dalam 2 siklus. Tiap siklus terdiri dari 2 pertemuan. Pelaksanaan kegiatan pembelajaran pada kondisi awal disesuaikan dengan RKH yang dibuat berdasarkan langkah metode demonstrasi dengan memperhatikan hasil pengamatan pada saat observasi awal. Pada kondisi awal kegiatan yang diberikan dalam pembelajaran adalah materi dengan tema Tanaman.

\section{Peningkatan Motorik Halus Anak Antar Siklus}

Berdasarkan hasil penelitian tindakan kelas tentang metode demonstrasi, yang bertujuan untuk meningkatkan kemampuan motorik halus anak sudah mengalami peningkatan. Dengan membandingkan data-data yang sudah diperoleh selama penelitian yang berlangsung selama 2 siklus dan dapat dikatakan bahwa proses pembelajaran telah mencapai tujuan yang diharapkan.

Pengisian lembar observasi motorik halus anak untuk mengukur peningkatan motorik halus anak. Pada skor pra tindakan sebelum dilakukan tindakan penelitian sebesar 49,33, pada siklus I motorik halus anak naik menjadi 87,24 dan pada siklus II motorik halus anak meningkat menjadi 96,10.

Penelitian ini senada dengan pendapat Solehudin (2000). Kemampuan motorik halus sangat penting karena berpengaruh pada segi pembelajaran lainnya.

Berdasarkan hasil dari analisis data menunjukkan bahwa terdapat peningkatan hasil motorik halus anak pada tiap siklusnya. Dari rata-rata nilai pada tahap pra tindakan yaitu 49,33 dengan ketuntasan klasikal 33\%
Kategori Mulai Berkembang (MB). Setelah dilaksanakan tindakan pada siklus I nilai ratarata hasil motorik halus anak mencapai 87,24 dengan ketuntasan 76,19\% dengan kategori Berkembang Sesuai Harapan (BSH). Meskipun demikian pembelajaran menggunakan metode demonstrasi pada siklus I belum maksimal. Kemudian dilanjutkan perbaikan di siklus II sebagai hasil refleksi pada siklus I. Pada siklus II rata-rata nilai hasil motorik halus anak menjadi 96,10 dengan kategori Berkembang Sangat Baik (BSB) dengan ketuntasan klasikal $86 \%$.

ketuntasan klasikal motorik halus anak pada pra tindakan sebesar 33\%, naik menjadi $76,19 \%$ pada siklus I, dan meningkat pada siklus II sebesar $86 \%$.

Peningkatan motorik halus anak yang menerapkan metode demonstrasi disebabkan anak secara aktif mengerjakan kegiatan yang diberikan dengan baik. Anak harus bekerja sendiri atau berkelompok untuk menyelesaikan kegiatan melalui berbagai macam cara atau gerakan-gerakan yang dilakukan oleh anak. Sesuai dengan pendapat Syaiful (2006:210). “ Metode demonstrasi merupakan" metode yang digunakan dengan cara mengajarkan bahan-bahan pelajaran yang merupakan suatu gerakan-gerakan, suatu proses maupun hal-hal yang bersifat rutin. Dengan metode demonstrasi peserta didik berkesempatan mengembangkan kemampuan mengamati segala benda yang sedang terlibat dalam proses serta dapat mengambil kesimpulan-kesimpulan yang diharapkan.

Guru juga memberikan penghargaan kepada anak apabila anak sudah menyelesaikan rangkaian kegiatan yang diberikan dari awal sampai selesai, merangsang anak untuk melatih otot-otot jemari, kecepatan, ketelitian, kerapian melalui gerakan-gerakan sederhana serta melatih kelenturan motorik halusnya melalui kegiatan menempel pasir pada kertas yang berpola. Anak-anak mulai senang dengan kegiatan melalui metode demonstrasi sehingga motorik halus anak mengalami peningkatan. Kegiatan terasa menyenangkan setelah menggunkan metode demonstrasi dibandingkan dengan sebelumnya yang tidak memakai metode demonstrasi. Dilihat dari persentase motorik halus anak yang selalu 
mengalami peningkatan dalam setiap siklusnya. Pembelajaran dengan menggunakan metode demonstrasi motorik halus anak meningkat. Hal ini juga dapat dilihat dari nilai rata-rata motorik halus anak yang mengalami peningkatan dalam siklus dan pada akhir proses kegiatan pembelajaran ketuntasan klasikal mencapai $86 \%$.

Berdasarkan hasil yang diperoleh, maka terbukti bahwa metode demonstrasi dapat meningkatkan motorik halus anak Kelompok A usia 3-4 tahun di PAUD Riyadlusshibyan. Menurut teori Anisatul (2009:87), bahwa kelebihan metode demonstrasi adalah terjadinya verbalisme akan dapat dihindari, siswa disuruh langsung memperhatikan bahan pelajaran yang dijelaskan, sehingga proses pembelajaran akan lebih menarik, dengan cara mengamati secara langsung oleh siswa akan memiliki kesempatan untuk membandingkan antara teori dan kenyataan.

Pada Siklus I kegiatan yang diberikan dalam pembelajaran adalah materi dengan tema Tanaman. Anak-anak diberikan kegiatan untuk mengisi sebuah pola gambar bunga yang sudah disediakan guru, anak-anak menjadi senang karena pembelajaran yang diberikan menarik. Sehingga anak-anak dapat menyelesaikan kegiatan dengan tuntas.

Pada siklus I ada beberapa anak yang belum bisa mengisi pola buatan guru, alasannya dikarenakan anak-anak belum bisa menggerakkan otot jari-jemari tangan dengan baik, masih kaku dalam memegang sesuatu benda, sehingga anak-anak merasa kesulitan untuk berkegiatan. Perkembangan motorik halus anak pada hal ini masuk kategori MB.

Pada siklus II, perkembangan motorik halus anak sudah menunjukkan kelenturan otot jarijemari tangan, dikarenakan anak-anak mendapat stimulasi yang tepat, dengan cara memberikan kegiatan dengan tema tanaman, sub tema bunga dengan cara mengisi pola gambar menggunakan pasir dengan metode demonstrasi. Metode demonstrasi ini dapat melatih kelenturan tangan anak, kecepatan tangan, ketelitian dan kerapian dalam mengisi suatu pola gambar, ditambah dengan pemberian reward berupa bintang yang diberikan oleh guru.
Dari hasil pelaksanaan tindakan siklus II menunjukkan adanya peningkatan motorik halus anak, hal ini terjadi karena anak melakukan kegiatan dengan penuh rasa gembira, anak-anak dapat melaksanakan metode demonstrasi dengan baik dan melakukan dengan penuh kesabaran dari awal sampai selesai sehingga hasil dari kegiatan anak-anak cukup rapi, karena perkembangan motorik halus anak dapat berkembang dengan baik dan sesuai harapan peneliti, motivasi yang diberikan guru kepada anak serta suasana gembira yang kondusif dan kebebasan yang diberikan untuk melakukan kegiatan melalui metode demonstrasi dapat membuat motorik halus anak berkembang. Sehingga perkembangan motorik halus anak tiap siklusnya mengalami peningkatan, sehingga bisa dikatakan perkembangannya Baik (BSB). Meskipun demikian masih ada beberapa anak yang masih masuk kategori MB, dikarenakan masih butuh bimbingan dari guru. Perkembangan motorik halus anak meningkat disetiap siklusnya. Sehingga melalui metode demonstrasi ini dapat meningkatkan motorik halus anak menggunakan media pasir.

\section{KESIMPULAN}

Berdasarkan hasil penelitian dan pembahasan dari penelitian tindakan kelas ini, diperoleh kesimpulan bahwa dengan menggunakan metode demonstrasi dengan tema Tanaman dapat meningkatkan motorik halus anak pada Kelompok A usia 3-4 tahun di PAUD Riyadlusshibyan tahun pelajaran 2019/ 2020. Pada saat kegiatan proses belajar mengajar berlangsung di tiap siklusnya, anak merasa senang mengerjakan kegiatan yang diberikan karena menggunakan media pasir, pola gambar dan lem yang disenangi oleh anak, anak tidak mudah bosan dalam proses pembelajaran, sehingga kemampuan motorik halus anak dapat berkembang sesuai harapan guru dan peneliti, perkembangan motorik halus anak terlihat dari empat aspek yaitu : ketelitian, kecepatan, kelenturan, dan kerapian. Hasil peningkatan menggunakan metode demonstrasi mengalami peningkatan untuk setiap siklusnya. Pada siklus I hasil keterlaksanaan observasi motorik halus anak 
sebesar $76,19 \%$ dan mengalami peningkatan menjadi $86 \%$ pada siklus II.

Penggunaan metode demonstrasi dapat meningkatkan motorik halus anak dalam pra tindakan sebesar 33\%, siklus I 76,19\%, dan meningkat menjadi $86 \%$ pada siklus II. Penggunaan metode demonstrasi pada pembelajaran denga tema Tanaman, nilai ratarata sebelum penelitian sebesar 49,33 dengan ketuntasan klasikal sebesar $33 \%$ dengan kategori Mulai Berkembang (MB), pada siklus I nilai rata-rata motorik halus anak mengalami peningkatan sebesar 87,24 dengan ketuntasan klasikal 76,19\% dengan kategori Berkembang Sesuai Harapan (BSH), pada siklus II nilai rata-rata kelas mengalami peningkatan sebesar 96,10 dengan ketuntasan sebesar $86 \%$ dengan kategori Berkembang Sangat Baik (BSB).

Berdasarkan uraian diatas, membuktikan bahwa melalui metode demonstrasi dapat meningkatkan motorik halus anak. Anak menjadi aktif menggerakkan jari-jemari tangan.

\section{DAFTAR PUSTAKA}

Anissatul Mufarokah. (2009). Strategi Belajar Menagajar, (Yogyakarta : Teras).

Asrori, M. (2007). Psikologi Pembelajaran. Bandung : CV Wacana Prima.

Artikel Kemampuan Motorik Halus Anak Usia Dini (PAUD) merupakan bagian dari Mengenal Perkembangan Motorik Anak Usia Dini (PAUD).

Azhar Lalu Muhammad. (1991). Proses Belajar Mengajar. Surabaya : Usaha Nasional.

Aqib, Zaenal. (2006). Penelitian Tindakan Kelas Untuk Guru. Bandung : Rama.

Bahri, Syaiful. (2005). Strategi Belajar Mengajar. Jakarta : Rineke Cipta.

MS. Sumantri. (2005). Model Pengembangan Keterampilan Motorik Anak Usia Dini. Jakarta : Depdiknas, Dirjen Dikti.

Depdiknas. (2007). Pedoman Pengembangan Fisik/Motorik Di Taman Kanal-Kanak. Jakarta.

Elizabeth B. Hurlock. (1978). Perkembangan Anak. Jakarta : Erlangga.
Hanafiah Nanang dan Cucu Suhadi. (2009). Konsep Strategi Pembelajaran. Bandung: Refika Aditama.

Iskandar. (2011). Penelitian Tindakan Kelas. Jakarta : GP Press.

Jalaludin. (1998). Psikologi Agama. Jakarta : PT Raja Grafindo.

M. Sinaga Anggiat dan Sri Hadiati. (2001). Pemberdayaan Sumber Daya Manusia. Jakarta : Lembaga Administrasi Negara Republik Indonesia.

Moedjiono, Dimyati. (1993). Stategi Belajar Mengajar. Jakarta : Departemen Pendidikan dan kebudayaan Nasional.

Maxim. (1993). Perkembangan dan Konsep Dasar Perkembangan Anak Usia Dini. Jakarta: Dirjen Dikti.

Miles Matthew B. dan A. Michael Huberman. (1992). Analisis Data Kualitatif. Diterjemahkan oleh Tjetjep Rohendi Rohidi. Jakarta : Universitas Indonesia Press.

MS. Sumantri. (2005). Pengembangan Ketrampilan Motorik Anak Usia Dini. Jakarta : Dinas Pendidikan.

Muhibbin Syah. (2005). Psikologi Pendidikan. Bandung : Remaja Rosda Karya. Mayke. (2007). Melatih Keterampilan Anak. (Online). Tersedia di : http://www.plbjabar.com. (Akses : 6 September 2017).

Neuneu Nur Alam. (2014). Upaya Meningkatkan Keterampilan Motorik Halus Anak Melalui Kegiatan Bermain Pasir: Universitas Pendidikan Indonesia.

Risaldy, Sabil dan Meity H.I. (2014). Panduan Mengatasi Permasalahan Anak Usia

Dini. Jakarta : PT. Luxima Metro Jaya.

Syaiful. (2006). Konsep Dan Makna Pembelajaran. Jakarta : Alfabet.

Suyanto. (1997). Pedoman Pelaksanaan Penelitian Tindakan Kelas. Yogyakarta : IKIP Yogyakarta.

Suharsimi Arikunto. (1993). Prosedur Penelitian Suatu Pendekatan Praktek. Jakarta : PT. Rineka Cipta.

Sutrisno Hadi. (1985). Metodologi Research, Yogyakarta : UGM. 
Sutan Surya. (2006). Panduan Menulis Skripsi (Tesis, Disertasi dan Karya Ilmiyah). Yogyakarta : Pustaka Pena.

Syah, Muhibbin. (2003). Psikologi Belajar. Jakarta : Raja Grafindo Persada.

Sumiawan. (2003). Belajar dan Pembelajaran Dalam Taraf Usia Dini. Jakarta : PT Ikrar Mandiri Abadi.

Suyadi. (1982). Bimbingan Konseling Untuk PAUD. Yogyakarta : Diva Press.

Solehudin. (2000). Konsep Dasar Pendidikan Pra Sekolah. Bandung : UPI.

Trianto, (2010). Medendesain Model Pembelajaran Inovatif-Progresif : Konsep, Landasan, dan Implementasinya pada Kurikulum Tingkat Satuan Pendidikan (KTSP). Jakarta : Kencana Prenada Media Group.

http:/www.scribd.com/doc/94367221/Perkem bangan Anak Usia Dini. (Akses 6 September 2017).

Sumber : http/mthp.blogspot.com/ (Akses 6 September 2019). 